\title{
Acholeplasma bactoclasticum sp. n., an Anaerobic Mycoplasma from the Bovine Rumen
}

\author{
JOHN P. ROBINSON ${ }^{1}$ and R. E. HUNGATE \\ Department of Bacteriology, University of California, Davis, California 95616
}

\begin{abstract}
A strain of a strictly anaerobic, filterable, bacteriolytic microorganism has been isolated from the bovine rumen. It has the microscopic and colonial morphology characteristic of mycoplasmas and is resistant to penicillin G. Sterols are not required for growth, and physiological properties show it to be distinct from Acholeplasma laidlawii, A. granularum, and A. axanthum. It is proposed that the organism be named Acholeplasma bactoclasticum sp. $\mathrm{n}$. The type strain is ATCC 27112 .
\end{abstract}

Microorganisms causing a partial digestion of rumen bacterial cells included in an agar culture medium were initially thought to meet their energy needs by a fermentation of protein (6, p. 79). A rapid digestion of the casein in skim milk was observed, and addition of glucose to the medium did not greatly increase the size of the colonies.

The work reported here describes the results of experiments and observations identifying a similar microorganism as a new species of Acholeplasma establishing some of its characteristics.

\section{MATERIALS AND METHODS}

Bacterial strain. The strain reported here was isolated from rumen fluid siphoned from a fistulated Jersey heifer. It was deposited in the American Type Culture Collection, Rockville, Md. as ATCC 27112.

Preparation of media and supplements. The organism was cultured anaerobically under $100 \% \mathrm{CO}_{2}$ by the roll-tube technique (7). Cysteine $(0.03 \%)$ and $\mathrm{NaHCO}_{3}(0.05 \%)$ (both wt/vol in final concentration) were added anaerobically with a syringe before autoclaving. The $3 \% \mathrm{Na}_{2} \mathrm{~S} \cdot 9 \mathrm{H}_{2} \mathrm{O}$ solution routinely added to provide a low redox potential was prepared by dissolving the crystals in boiled deionized water cooled under $\mathrm{O}_{2}$-free $\mathrm{N}_{2}$, tubed anaerobically under $\mathrm{N}_{2}$, and autoclaved. Final concentration in the medium was $0.03 \% \mathrm{Na}_{2} \mathrm{~S} \cdot 9 \mathrm{H}_{2} \mathrm{O}$. Carbohydrate solutions were autoclaved under $\mathrm{CO}_{2}$ to minimize alkaline destruction during sterilization. Sulfide and carbohydrate solutions were injected aseptically and anaerobically into the melted medium held at $48 \mathrm{C}$. The osmotic pressure of the media used was about 7 atmospheres, and the $\mathrm{pH}$ was 6.8 .

Skim milk was autoclaved in 10-ml volumes under $\mathrm{N}_{2}$ in butyl-stoppered tubes.

${ }^{1}$ Present address: Department of Plant Biology and Microbiology, Queen Mary College, Mile End Road, London E1, England.
A mineral salts basal medium was prepared by adding four volumes of deionized water to one volume each of mineral solutions $\mathrm{A}\left(0.3 \% \mathrm{KH}_{2} \mathrm{PO}_{4}, 0.6 \%\right.$ $\mathrm{NaCl}, 0.3 \%\left(\mathrm{NH}_{4}\right)_{2} \mathrm{SO}_{4}, 0.06 \% \mathrm{MgSO}_{4} \cdot 7 \mathrm{H}_{2} \mathrm{O}, 0.06 \%$ $\left.\mathrm{CaCl}_{2} \cdot 2 \mathrm{H}_{2} \mathrm{O}\right)$ and $\mathrm{B}\left(0.3 \% \mathrm{~K}_{2} \mathrm{HPO}_{4}\right)$, all w/v.

Minfav medium. Minerals salts-volatile fatty acidvitamin (Minfav) medium was prepared by adding vitamins and volatile fatty acids to the mineral salts medium. The vitamin solution contained the following, dissolved in $500 \mathrm{ml}$ of water: biotin, $1 \mathrm{mg}$; calcium pantothenate, $200 \mathrm{mg}$; folic acid, $1 \mathrm{mg}$; inositol, 1,000 mg; niacin, $200 \mathrm{mg}$; riboflavine, 100 $\mathrm{mg}$; and thiamine hydrochloride, $200 \mathrm{mg}$. Each $10 \mathrm{ml}$ of medium contained $10 \mu$ liters of this solution. The volatile acid mixture contained $17 \mathrm{ml}$ of acetic acid, 6 $\mathrm{ml}$ of propionic acid, $4 \mathrm{ml}$ of butyric acid, $1 \mathrm{ml}$ of $n$-valeric acid, $1 \mathrm{ml}$ of isovaleric acid, and $1 \mathrm{ml}$ of DL-methyl butyric acid; $0.03 \mathrm{ml}$ of the mixture was neutralized with $\mathrm{NaOH}$ and added to each $10 \mathrm{ml}$ of culture.

CRF medium. Clarified rumen fluid (CRF) medium was similar to the mineral salts medium except that two volumes of rumen fluid freed of cells by centrifugation were substituted for two volumes of deionized water. Rumen fluid was centrifuged at $25,000 \times g$ for $15 \mathrm{~min}$, and the supernatant fluid was added to the cooled mineral salts solution. Rumen fluid medium (RF medium) was prepared by using uncentrifuged rumen fluid freed of protozoa and plant material.

Skim milk medium. This medium, used for viable counts, contained $0.2 \mathrm{ml}$ of sterile skim milk added to $4.25 \mathrm{ml}$ of rumen fluid-agar medium.

CC medium. Concentrated cells medium (CC medium), relatively free of protozoa and plant material, was prepared by allowing the rumen liquor, as collected, to incubate at $38 \mathrm{C}$. Fermentation gases carried plant matter to the surface, the protozoa sank to the bottom, and the rumen fluid containing bacteria was drawn off from the middle part of the container with a $50-\mathrm{ml}$ pipette.

This rumen fluid was centrifuged at $25,000 \times g$ for $15 \mathrm{~min}$. The pellet was suspended with CRF medium to one-tenth the original volume, and one part of this 
$10 \times$ concentrated bacterial suspension was added to one part of mineral salt solution and one part of deionized water.

Tryptone (1\%, Difco), 3\% tryptone-soy broth (Oxoid), $1.3 \%$ nutrient broth (Oxoid), and $3.7 \%$ brain heart infusion (Oxoid) were prepared under 100\% $\mathrm{CO}_{2}$ and buffered with $0.5 \% \mathrm{NaHCO}_{3}$.

Isolation procedures. Samples of rumen fluid were siphoned from a fistulated Jersey heifer and poured into a flask until it was almost full. The flask was stoppered, insulated, and quickly transferred to the laboratory. Oxygen-free $\mathrm{CO}_{2}$ was bubbled through the sample to displace the air above it, and $0.5 \mathrm{ml}$ of the stirred fluid was diluted with 1-ml syringes through tubes of anaerobic medium. Lower dilutions were in sterile $33 \%$ RF medium and higher ones were in the $\mathrm{CC}$ medium containing $1.5 \%$ agar, which was melted and held at $48 \mathrm{C}$. The viable count was not detectably changed by holding as long as $2 \mathrm{~h}$ at this temperature before rolling the tubes in ice water. Tubes were always rolled within $30 \mathrm{~min}$ after inoculation. The cultures were incubated at $39 \mathrm{C}$ or $45 \mathrm{C}$ and examined periodically for clear zones due to partial digestion of the rumen bacteria in the medium.

Pure cultures were obtained by picking individual colonies with a Pasteur pipette drawn out to a thin capillary and subculturing in agar medium until, in two successive dilution series from a colony in high dilution, only the clearing colonies appeared and their numbers in successive tubes decreased in approximate agreement with the dilution. There were no problems with contamination.

Hydrogen measurement. Hydrogen was measured on a Perkin-Elmer thermal conductivity vapor fractometer $154 \mathrm{~B}$ with a silica gel column and $\mathrm{N}_{2}$ carrier gas. The instrument detected $10^{3} \mu \mathrm{mol}$ of $\mathrm{H}_{2}$ in a $0.5-\mathrm{ml}$ sample.

The volume of excess gas in the culture and control tubes was measured at atmospheric pressure with a 5or 10-ml syringe and injected back into the tube after each measurement. A sample in excess of $0.5 \mathrm{ml}$ was then drawn into a water-lubricated, sterile 1-ml glass syringe through a 21 -gauge needle. The tip of the needle was drawn into the rubber of the stopper to allow the gas to come to atmospheric pressure. The volume was noted, the needle was withdrawn, the volume was reduced to $0.5 \mathrm{ml}$, and the gas was injected into the fractometer.

Ammonia determination. When ammonia was to be measured, the $\left(\mathrm{NH}_{4}\right)_{2} \mathrm{SO}_{4}(3 \mathrm{~g} /$ liter $)$ in the mineral salts solution was omitted, and $\mathrm{Na}_{2} \mathrm{SO}_{4}(2.2 \mathrm{~g} /$ liter $)$ was added. Ammonia was assayed by the method of Ternberg and Hershey (11).

Gas chromatography of fatty acids. Samples of culture medium were centrifuged for $15 \mathrm{~min}$ at $25,000 \times g$, and then a $0.7-\mathrm{ml}$ sample was cooled to 4 $\mathrm{C}$ and acidified with $0.3 \mathrm{ml}$ of $85 \%$ phosphoric acid. After acidification, the sample was rapidly filtered through a $0.22-\mu \mathrm{m}$ membrane filter by using a glass syringe with a "Swinney" adapter, and kept at $4 \mathrm{C}$ before injection directly into a Hewlett-Packard 700 flame ionization, dual-column gas chromatograph fitted with a stainless steel column ( 60 by $1 / 8$ inches) packed with FFAP (14\% polyethylene glycol dinitrophthalic acid ester on chromosorb W). The carrier gas was helium at a flow rate of $13 \mathrm{ml} / \mathrm{min}$. The column temperature was $160 \mathrm{C}$.

Determination of fermentation products with uniformly labeled ${ }^{14} \mathrm{C}$-galactose. The ${ }^{14} \mathrm{C}$-galactose was supplied in $20 \%$ ethanol solution. A $12-\mu$ liter amount was transferred with a micro-syringe to each of two culture tubes. The ethanol was evaporated in a stream of air, and $0.6 \mathrm{ml}$ of $9 \%$ galactose was added to each tube under $\mathrm{CO}_{2}$. Sterile, anaerobic RF medium was prepared, and $9.4 \mathrm{ml}$ of the medium was added to the galactose which had been sterilized under $\mathrm{CO}_{2}$. Control tubes lacked the ${ }^{14} \mathrm{C}$-galactose. Initial 1 -ml samples were removed after inoculation with $0.1 \mathrm{ml}$ of a CRF/milk culture, and the cultures were incubated at $43 \mathrm{C}$ for 1 week.

A 1-ml amount of $10 \mathrm{~N}$ sulfuric acid was injected through the stopper of the culture tube, and the tube was shaken. The released $\mathrm{CO}_{2}$ was collected in a water-lubricated $10-\mathrm{ml}$ syringe while the tube and syringe were shaken to insure equilibrium of $\mathrm{CO}_{2}$ between gas and liquid. The volume of gas in the syringe as well as the pressure were noted at room temperature, and the gas was injected into a stoppered flask containing $10 \mathrm{ml}$ of 2,2,2-nitrilotriethanolamine, a sample of which was assayed with the scintillation counter.

Samples of the acidified culture $(0.5$ or $1.0 \mathrm{ml})$ were chromatographed on a Celite column by the method of Wiseman and Irvin (13). Samples of the eluant were assayed for ${ }^{14} \mathrm{C}$ in a liquid scintillation counter (Nuclear-Chicago Mk II).

The ${ }^{14} \mathrm{C}$ in trichloroacetic acid-insoluble material was assayed by collecting the $5 \%$ cold trichloroacetic acid precipitate from a sample of culture on a $0.45-\mu \mathrm{m}$ membrane filter (Millipore Corp.). The filter was washed with $5 \%$ trichloroacetic acid, dried, and dissolved in the counting fluid, $0.4 \mathrm{~g}$ of $1,4 \mathrm{bis}[2-(5$ phenyloxazolyl)]-benzene (POPOP, Packard Corp.) and $4 \mathrm{~g}$ of 2,5 diphenyloxazole in 1 liter of toluene.

Preparation of samples for electron microscopy. Colonies in CRF-agar were prefixed for $1 \mathrm{~h}$ in a Kellenberger buffer containing $0.2 \%$ glutaraldehyde, $0.1 \mathrm{~g}$ of $\mathrm{OsO}_{4} / 10 \mathrm{ml}$, and sufficient sucrose to make the buffer and the medium isotonic. The buffer contained $5 \mathrm{ml}$ of Veronal acetate $(2.94 \mathrm{~g}$ of sodium barbiturate, $1.94 \mathrm{~g}$ of hydrated sodium acetate, and $3.4 \mathrm{~g}$ of $\mathrm{NaCl}$ in $300 \mathrm{ml}$ ), $13 \mathrm{ml}$ of water, $0.25 \mathrm{ml}$ of $\mathrm{CaCl}_{2}(0.01 \mathrm{M})$, and $7.0 \mathrm{ml}$ of $0.1 \mathrm{M} \mathrm{HCl}$. The $\mathrm{pH}$ of the buffer was adjusted to 6 with $\mathrm{HCl}$.

After prefixation, the colonies were rinsed with buffer and fixed overnight in buffer containing $1 \%$ osmium tetroxide. The agar blocks containing the fixed colonies were dehydrated in alcohol, washed in propylene oxide, and embedded in "Bojax \#1 A" (52.1\% dodecenyl succinic anhydride, $34.7 \%$ Araldite $60005,1.7 \%$ dibutyl phthalate, and $11.5 \%$ Epon 812 ). Benzyldimethylamine was added as a catalyst, and the embedded blocks were sectioned with a diamond knife.

Serology. The slide agglutination test was used to detect cross-reaction of the antigen with various antisera (Table 1). The antisera were diluted in $0.85 \%$ $\mathrm{NaCl}$, and one drop of each dilution was mixed with one drop of antigen suspension. The mixture was gently shaken on a rotary shaker for $3 \mathrm{~min}$, and then 
the various dilutions were examined for flocculated cells.

The antigen was grown in 4-liter cultures of $33 \%$ CRF medium with vitamins and volatile fatty acids added. After harvesting, the cells were washed once and suspended in diluent to give an optical density at $600 \mathrm{~nm}$ of 3.0 . The diluent was prepared by mixing equal parts of $0.067 \mathrm{M} \mathrm{KH}_{2} \mathrm{PO}_{4}(9.073 \mathrm{~g} /$ liter $)$ and $0.067 \mathrm{M} \mathrm{NaHPO} 4(9.465 \mathrm{~g} /$ liter $)$, giving a pH of 6.8 . This was diluted 10 times with $0.85 \% \mathrm{NaCl}$, and aqueous merthiolate was added to a final concentration of $1: 10,000$.

Lytic activity. CRF-milk culture supernatant fluid containing $0.1 \%$ mercaptoethanol was precipitated with $65 \%$ ammonium sulfate under $100 \% \mathrm{CO}_{2}$. After centrifugation in air, the precipitate was taken up in $0.1 \mathrm{M}$ phosphate buffer $(\mathrm{pH}$ 7) containing $0.1 \%$ mercaptoethanol, dialyzed, and concentrated by pressure dialysis with a UM-2 membrane (Diaflow, Amicon Corp.). For measurement of lytic activity, small samples of this concentrated solution were added to substrate in stoppered tubes containing $100 \% \mathrm{CO}_{2}-$ bicarbonate buffer ( $\mathrm{pH} 7), 0.1 \%$ mercaptoethanol, and $1 \mathrm{ml}$ of $\mathrm{H}_{2} \mathrm{~S}$. Incubation was at $50 \mathrm{C}$.

Escherichia coli murein sacculi were prepared by the method of Martin and Frank (9).

\section{RESULTS}

Numbers in the rumen. Table 2 shows the colony counts of samples of rumen contents collected at different times from fistulated cows, a sheep, hay, and water. Penicillin G $(5,000$ units $/ \mathrm{ml})$ could be added to decrease the growth of most bacterial colonies, allowing surer detection of the microorganism with no decrease in count.

The hay tested $(5 \mathrm{~g})$ was collected from the cow's stall at the time a rumen fluid sample was taken. It was mixed with $180 \mathrm{ml}$ of autoclaved rumen fluid and broken up in a Waring blender under $\mathrm{CO}_{2}$. A 5-g sample of the rumen fluid

TABLE 1. Strains of Mycoplasma and Acholeplasma from bovine and avian sources for slide agglutination

\begin{tabular}{|c|c|c|c|}
\hline Organism & Strain & Origin & Source \\
\hline 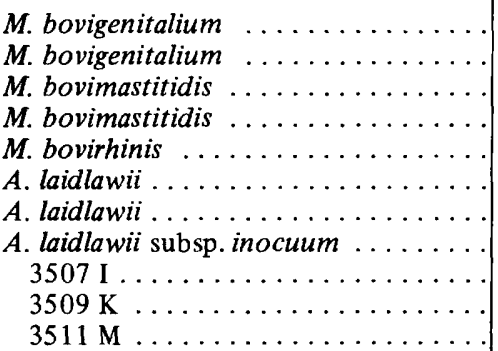 & $\begin{array}{l}\text { B6P } \\
1367 \\
\text { B38P } \\
01 \\
\text { FXT } \\
\text { B6P } \\
1063 \\
1527 \\
\text { B142P } \\
\text { B74P } \\
\text { B 144P }\end{array}$ & $\begin{array}{l}\text { Fabricant } \\
\text { UCD } \\
\text { Fabricant } \\
\text { UCD } \\
\text { Fabricant } \\
\text { Fabricant } \\
\text { UCD } \\
\text { H. E. Adler } \\
\text { Fabricant } \\
\text { Fabricant } \\
\text { Fabricant }\end{array}$ & $\begin{array}{l}\text { Bovine vagina } \\
\text { Bovine vagina } \\
\text { Bovine mastitic tissue } \\
\text { Bovine mastitic tissue } \\
\text { Bovine joints } \\
\text { Bovine endometrium } \\
\text { Tank milk } \\
\text { Chicken sinus } \\
\text { Bovine vagina } \\
\text { Bovine nose } \\
\text { Bovine joints }\end{array}$ \\
\hline
\end{tabular}

${ }^{a}$ University of California, Davis.

TABLE 2. Culture counts of cytoclastic organisms

\begin{tabular}{|c|c|c|c|c|}
\hline $\begin{array}{l}\text { Expt. } \\
\text { no. }\end{array}$ & Date & Source & Diet & $\begin{array}{c}\text { Colony-forming } \\
\text { units } / \mathrm{ml}\end{array}$ \\
\hline 1 & $11 / 4 / 65$ & Jersey rumen contents & Alfalfa hay & $4 \times 10^{6}$ \\
\hline 2 & $12 / 11 / 65$ & Jersey rumen contents & Alfalfa hay & $6 \times 10^{5}$ \\
\hline 3 & $2 / 1 / 66$ & Jersey rumen contents & Alfalfa hay & $4 \times 10^{6}$ \\
\hline $4^{a}$ & $3 / 11 / 68$ & Jersey rumen contents & Alfalfa hay + grain & $9 \times 10^{6}$ \\
\hline $5^{a}$ & $3 / 11 / 68$ & Holstein 1 rumen contents & Alfalfa hay + grain & $3 \times 10^{4}$ \\
\hline $6^{a}$ & $3 / 11 / 68$ & Holstein 2 rumen contents & Alfalfa hay & $1 \times 10^{6}$ \\
\hline $7^{a}$ & $11 / 4 / 68$ & Jersey rumen contents & Alfalfa hay + grain & $4 \times 10^{6}$ \\
\hline $8^{a}$ & $3 / 28 / 69$ & Sheep rumen contents & Alfalfa pellets & $3 \times 10^{5}$ \\
\hline $9^{a}$ & $3 / 30 / 69$ & Sheep rumen contents & Alfalfa pellets & $6 \times 10^{5}$ \\
\hline \multirow[t]{2}{*}{10} & $8 / 30 / 69$ & Jersey rumen contents & Alfalfa hay & $4 \times 10^{6}$ \\
\hline & & $\begin{array}{l}\text { Jersey rumen contents } \\
5 \mathrm{~g} \text { of alfalfa hay }\end{array}$ & Alfalfa hay & $\begin{array}{c}4 \times 10^{6} \\
0\end{array}$ \\
\hline \multirow[t]{4}{*}{11} & $10 / 27 / 69$ & Jersey rumen contents & Alfalfa hay & $1.4 \times 10^{5}$ \\
\hline & & Jersey rumen contents & Alfalfa hay & $2.0 \times 10^{5}$ \\
\hline & & Drinking water & & $8 \times 10^{\circ}$ \\
\hline & & Drinking water & & $1.4 \times 10^{1}$ \\
\hline
\end{tabular}

${ }^{a}$ Penicillin $\mathrm{G}(5,000 \mu$ liters $/ \mathrm{ml})$ in medium.

$b$ Sample mixed in Waring blender to simulate treatment of hay sample. 

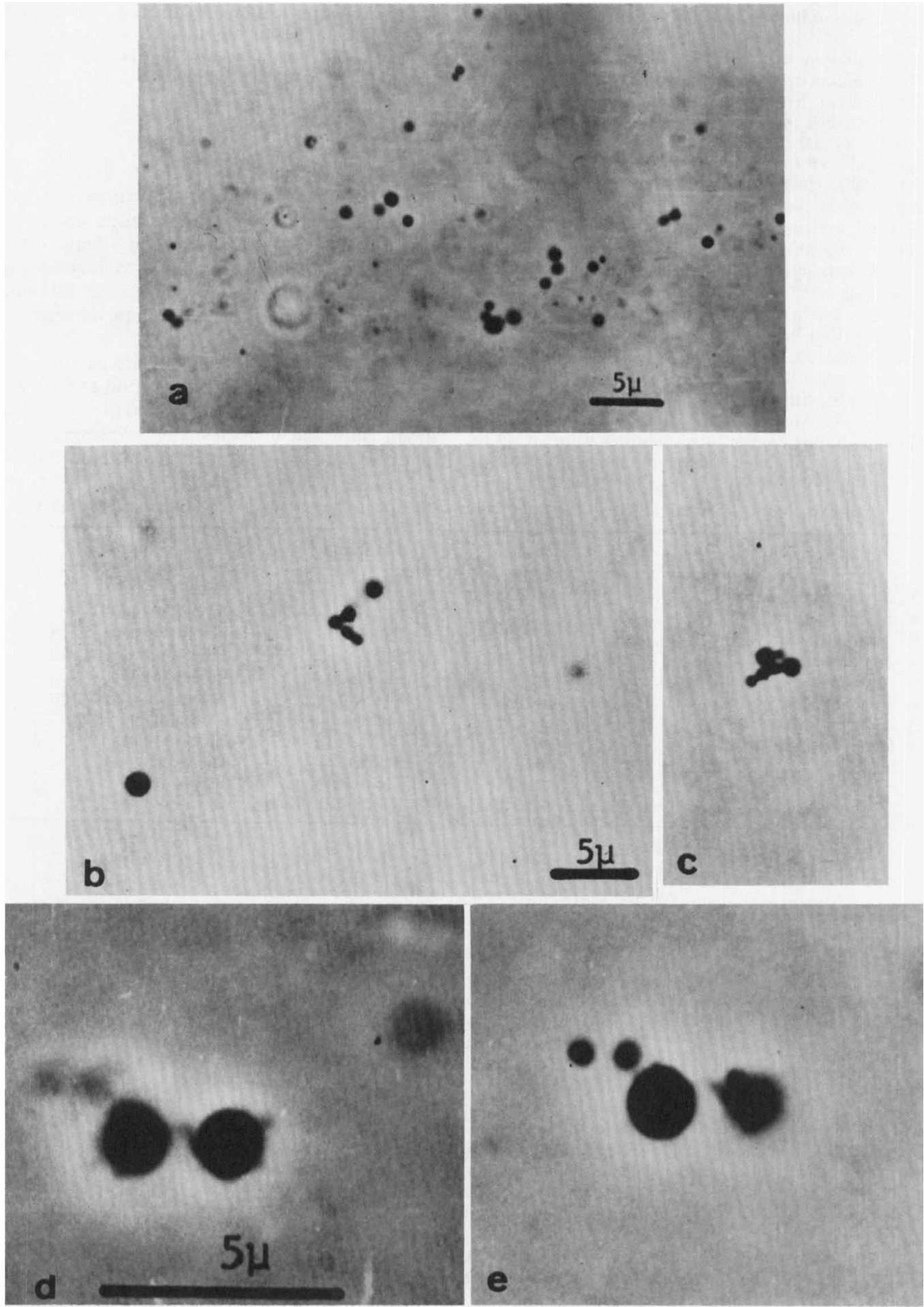

FIG. 1. Photomicrographs of fresh mounts of cultures in clarified rumen fluid medium. 
was similarly treated. Counts were made by decimal dilution of the samples through $30 \%$ CRF-agar containing $E$. coli cells plus penicillin and compared with similar counts made without blending. Samples of drinking water from the stall contained a few colony-forming units probably derived from cells entering the water as the animal drank. Clearing zones were not detected in agar series inoculated from two samples of human feces and one sample of deer rumen contents (Odocoileus hemionus hemionus).

Morphology. The organism is gram negative, coccoid, and varies in size from less than 0.5 to $2.0 \mu \mathrm{m}$ in diameter. Figure 1a shows the size variability typical in CRF-agar medium. In liquid culture, clusters of cells and short chains are common (Fig. $1 \mathrm{~b}$ and c). Large cells frequently appear to have surface projections (Fig. 1d and e) which are difficult to resolve with phase microscopy. These large cells are fragile and lyse easily in wet mounts. In old liquid cultures and in the centers of colonies, ghosts of these large cells, sometimes containing inclusions, are common.

Electron micrographs of sections through agar-grown colonies (Fig. 2) show cells of irregular outline bounded by a unit membrane, with no distinguishable cell wall. Some of the sections appear to be through clusters of cells similar to those seen with phase microscopy. The small membrane-bound vesicles may represent sections through projections from larger cells or through the smallest colony-forming units.

Surface colonies on CRF-agar reach a diameter of 1 to $1.5 \mathrm{~mm}$ after 5 days of incubation at $43 \mathrm{C}$. They appear white when viewed with reflected light and have the morphology typical of the Mycoplasmatales (Fig. 3 and 4). The colonies stain blue with Dienes stain (2).

Comparison with some known strains. The fistulated animals in which the microorganism has been found have all appeared healthy over a 5-year period. A milk $(0.2 \mathrm{ml}) \mathrm{CRF}$ culture in which the casein had cleared was injected into the yolk sac of chicken embryos, with autoclaved culture and sterile saline injected into controls. Table 3 shows the number of surviving embryos after 7 days of incubation. No deaths occurred in a second passage when yolk from two of these eggs was inoculated into 7-day yolk sacs. No viable cells developed in $30 \%$ CRF-milk broth inoculated from yolk sacs of

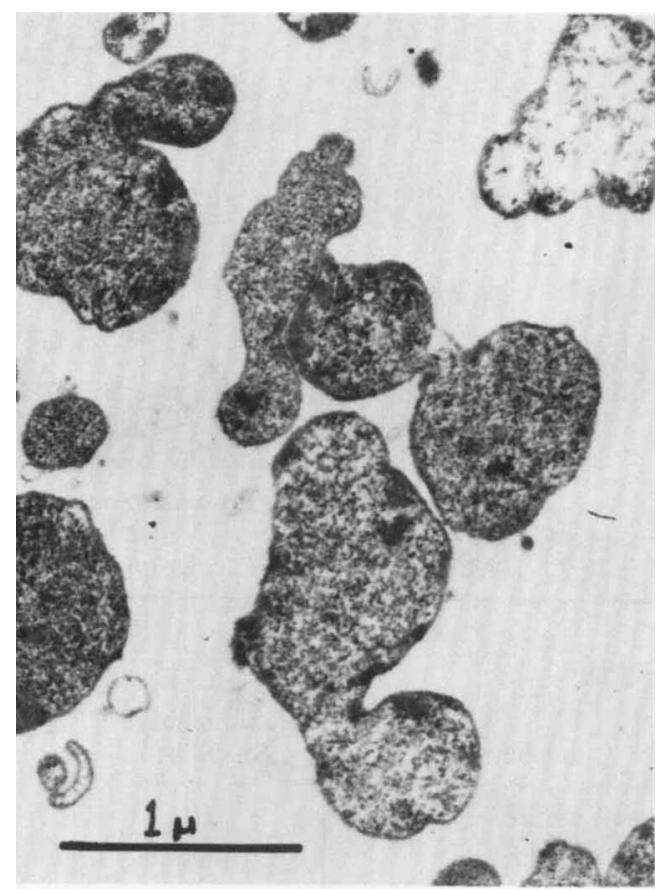

FIG. 2. Electron micrographs of a section through a colony grown on the surface of clarified rumen fluid agar.
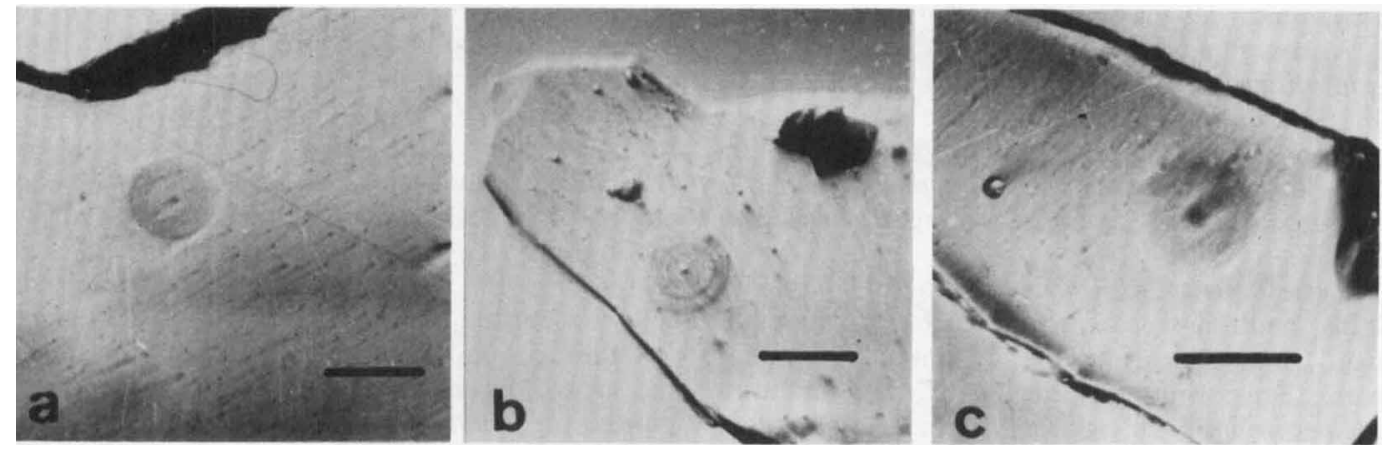

FIG. 3. Photomicrographs of surface colonies. Bar represents $1 \mathrm{~mm}$. 


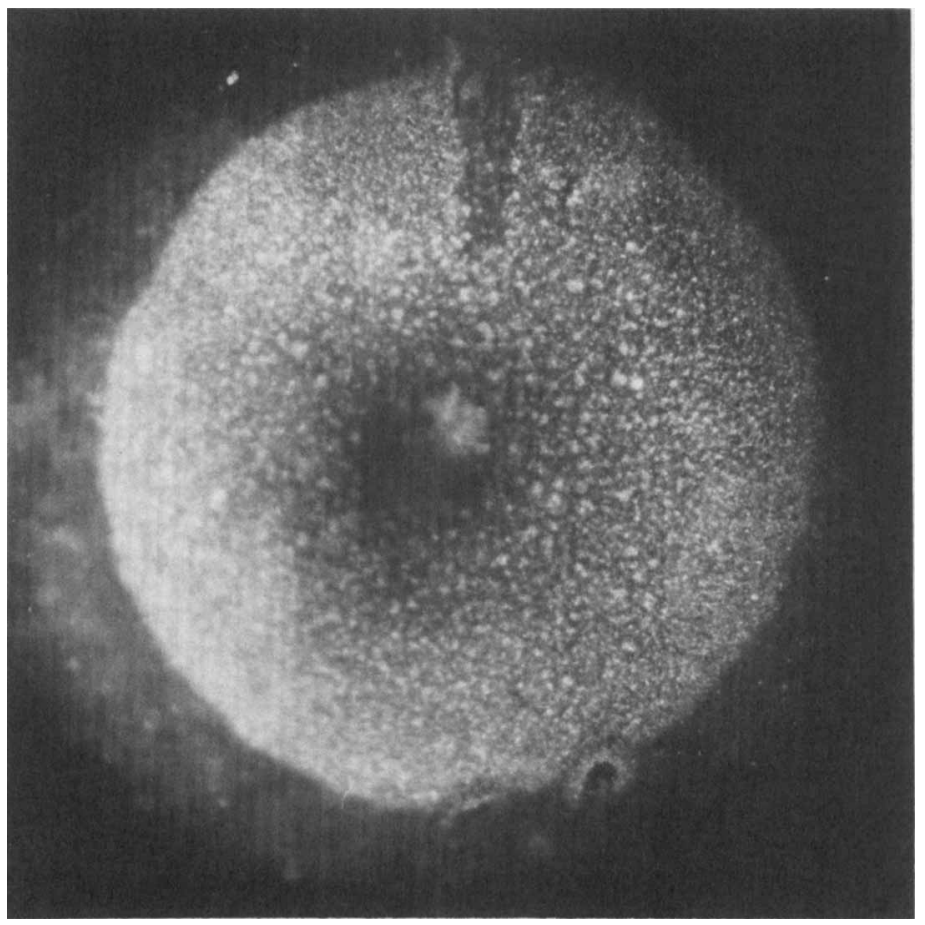

FIG. 4. Photomicrograph of surface colony. Magnification $\times 75$.

TABLE 3. Effect of inoculation of 7-day chicken embryos with the new microorganism

\begin{tabular}{|c|c|c|c|c|}
\hline \multirow[b]{2}{*}{ Inoculum } & \multicolumn{2}{|c|}{ First passage } & \multicolumn{2}{|c|}{ Second passage } \\
\hline & $\begin{array}{l}\text { No. of embryos } \\
\text { inoculated }\end{array}$ & $\begin{array}{c}\text { No. of embryos } \\
\text { dead } \\
\text { (7 days) }\end{array}$ & $\begin{array}{l}\text { No. of embryos } \\
\text { inoculated }\end{array}$ & $\begin{array}{c}\text { No. of embryos } \\
\text { dead } \\
\text { (7 days) }\end{array}$ \\
\hline $\begin{array}{l}\text { Viable culture } \ldots \ldots \ldots \\
\text { Autoclaved culture } \ldots \ldots \\
\text { Sterile saline } \ldots \ldots \ldots \ldots\end{array}$ & $\begin{array}{l}18 \\
15 \\
12\end{array}$ & $\begin{array}{l}1 \\
1 \\
0\end{array}$ & $\begin{array}{l}18 \\
12\end{array}$ & $\begin{array}{l}0 \\
0\end{array}$ \\
\hline
\end{tabular}

either group. No symptoms were detectable after accidental self-inoculation of one author with about $0.2 \mathrm{ml}$ of viable culture.

Antisera against two strains of $M$. bovigenitalium, two of $M$. mastitidis, one strain of $M$. bovirhinis, and three strains of $A$. laidlawii did not agglutinate the microorganism when its homologous titer was 180 . M. gallisepticum was not agglutinated by antiserum against the new isolate.

Lytic activity. Colonies growing in CRF-skim milk medium were surrounded by a somewhat oval zone of clearing (Fig. 5) and smaller zones were seen around colonies in CC-agar medium. Suspensions of autoclaved rumen bacteria were lysed by ammonium sulfate-precipitated culture supernatant fluid (Fig. 6), whereas live cells were less readily attacked. A similar result was obtained with autoclaved and live suspensions of E. coli, Salmonella typhimurium, and Spirillum serpens (Table 4). Murein sacculi of $E$. coli were lysed by a similar preparation (Fig. 7).

Freeze-dried $M$. lysodeikticus cells (Bactolysozyme Substrate, Difco) were not lysed by the culture supernatant fluid. Autoclaving and chloroform-methanol (2:1) extraction, which facilitated lysis of $E$. coli, $S$. typhimurium, and $S$. serpens, did not render the $M$. lysodeikticus cells susceptible to lysis (Table 5).

Other properties. The microorganism failed to grow on agar plates of CRF medium containing cysteine and $\mathrm{Na}_{2} \mathrm{~S}$, either aerobically or under $\mathrm{CO}_{2}$ in Brewer jars. Growth occurred anaerobically in roll tubes of the same 


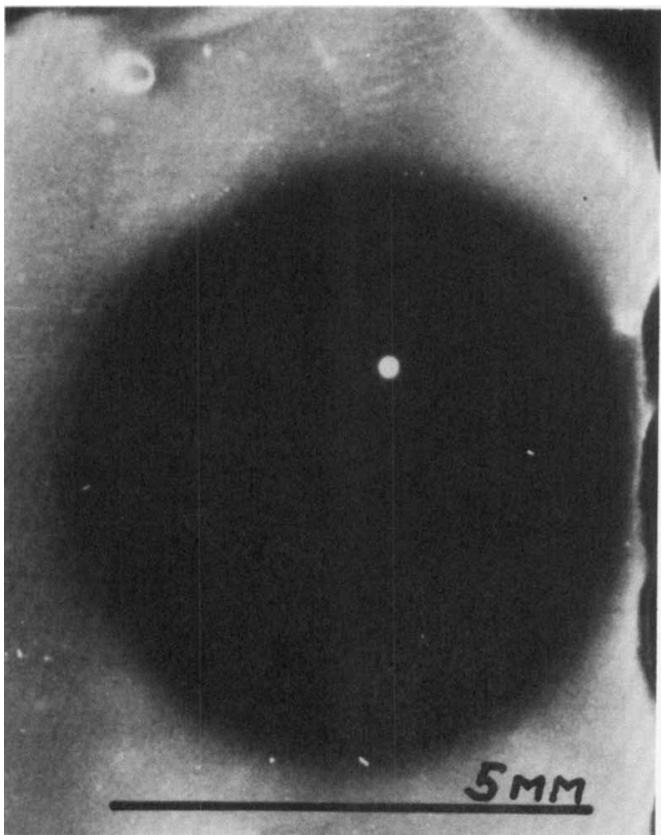

FIG. 5. Colony of Acholeplasma bactoclasticum surrounded by clearing due to casein digestion. addition of either penicillin or thallium acetate, and has not developed penicillin sensitivity.

Guinea pig, cow, or sheep blood at a concentration of $5 \%(\mathrm{vol} / \mathrm{vol})$ in CRF-agar medium containing $10 \mu \mathrm{mol}$ of galactose per $\mathrm{ml}$



FIG. 6. Lysis of live and autoclaved rumen bacteria by ammonium sulfate-precipitated lytic factor. Autoclaved cells (ㅁ), autoclaved cells control ( 1 ), live cells (०), live cells control $(\bullet)$.

TABLE 4. Lysis of heat-killed bacterial cells by ammonium sulfate precipitate of culture supernatant

\begin{tabular}{|c|c|c|c|}
\hline Substrate $^{a}$ & Initial OD & Final OD & $\begin{array}{l}\text { OD change } \\
\text { in } 100 \mathrm{~min}\end{array}$ \\
\hline \multicolumn{4}{|l|}{ Autoclaved cells } \\
\hline Spirillum serpens & .46 & .12 & -.32 \\
\hline S. serpens control & .44 & .36 & -.10 \\
\hline Salmonella typhimurium & .41 & .14 & -.27 \\
\hline S. typhimurium control & .29 & .27 & -.02 \\
\hline Escherichia coli & .80 & .29 & -.51 \\
\hline E. coli control & .64 & .56 & -.08 \\
\hline \multicolumn{4}{|l|}{ Live cells } \\
\hline Spirillum serpens & .56 & .19 & -.37 \\
\hline$S$. serpens control & .55 & .25 & -.30 \\
\hline Salmonella typhimurium & .48 & .39 & -.09 \\
\hline S. typhimurium control & .36 & .31 & -.05 \\
\hline E. coli & .95 & .89 & -.06 \\
\hline E. coli control & .72 & .64 & -.08 \\
\hline
\end{tabular}

${ }^{a}$ In the control tubes the lytic factor was boiled in buffer before substrate addition.

medium at 36,42 , and $45 \mathrm{C}$ but could not be detected after 2 weeks of incubation at 30 or 47 C. Growth was inhibited by $20 \mu \mathrm{g}$ of terramycin $/ \mathrm{ml}$ but not by 5,000 units of penicillin $\mathrm{G}$ per $\mathrm{ml}$. Thallium acetate $(0.025 \%)$ was not inhibitory in our experiments, but Allison and Robinson (personal communication) indicated that the thallium may have been precipitated by the sulfide used as a reducing agent. The microorganism has been subcultured weekly for 4 years in liquid medium without was not hemolyzed. Suspensions of tristearin, olive oil, maize oil, or tributyrin added to a similar medium at $1 \%(\mathrm{v} / \mathrm{v})$ concentration were not cleared. Arginine was not fermented.

The organism was filtered through a $0.45-\mu \mathrm{m}$ filter (Millipore Corp.). At $10 \mathrm{lb} / \mathrm{in}^{2}$ positive pressure, about $2 \%$ of a suspension of $5.1 \times 10^{5}$ cells $/ \mathrm{ml}$ was cultured from the filtrate. On other occasions, a few cells were recovered after passing a broth culture through a $0.22-\mu \mathrm{m}$ membrane filter. 


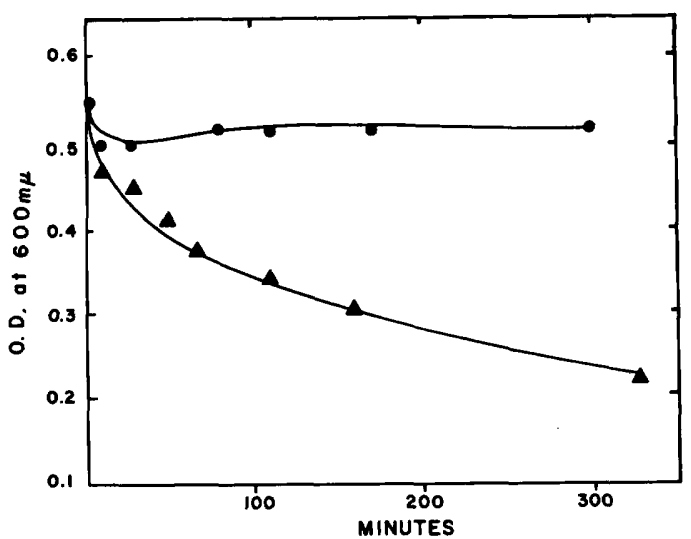

FIG. 7. Decrease in turbidity of R-layer suspension during incubation with ammonium sulfate-precipitated lytic factor in phosphate buffer $(p H 6.8)$ at $50 \mathrm{C}$. Factor $(\mathbf{4})$, boiled factor $(\bullet)$.

TABLE 5. Incubation of M. lysodiekticus cells in culture supernatant fluid

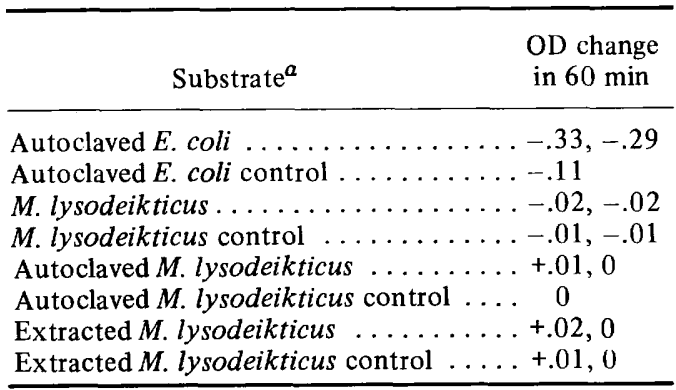

${ }^{a}$ In the control tubes the lytic factor was boiled in buffer before substrate addition.



FIG. 8. Effect, on colony-forming units per milliliter, of addition of a suspension of rumen bacteria to $2 \% C R F$ medium; $2 \% C R F(\Delta), 10 \mathrm{ml}$ of $2 \%$ CRF plus $0.05 \mathrm{ml}$ of cell suspension $(\bullet), 10 \mathrm{ml}$ of $2 \%$ CRF plus $2.0 \mathrm{ml}$ of cell suspension (०).

TABLE 6. Change in OD at 4 days in subcultures in mineral salts plus $E$. coli medium supplemented with various nutrients

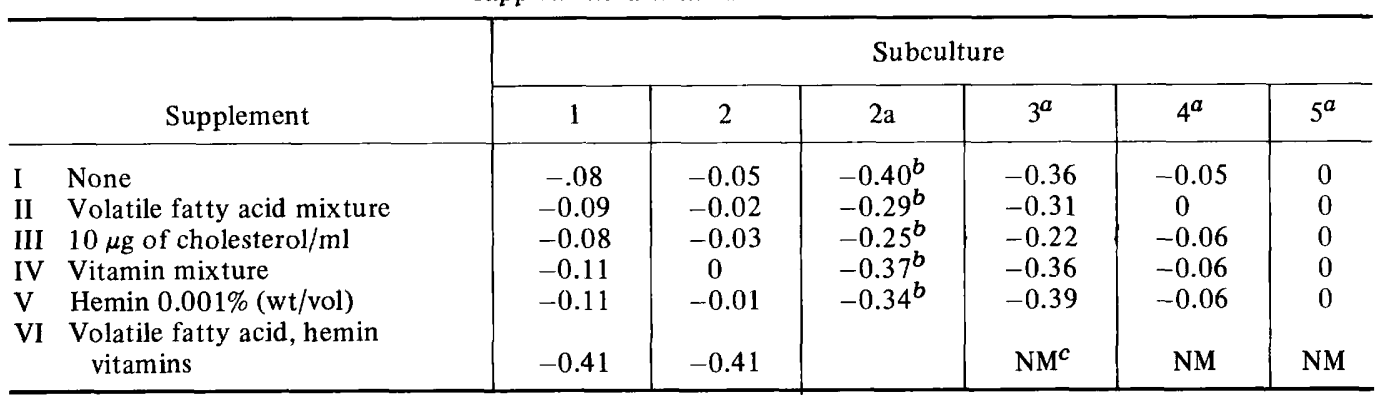

${ }^{a}$ Subcultures 3, 4, and 5 of all except supplement VI are from subculture $2 \mathrm{a}$ of the respective supplements.

$b$ Tube 2 incubated further after inoculation with $0.1 \mathrm{ml}$ of $33 \%$ CRF-milk culture.

$c$ NM, Not measured.

Nutrition. Mixed rumen bacteria added to $2 \%$ CRF medium increased cell counts (Fig. 8); a similar result was obtained with $E$. coli cells. Subculture experiments show that growth, indicated by clearing of the $E$. coli suspension, is not sustained in $E$. coli-mineral salts medium unless volatile fatty acids, hemin, and vitamins or CRF are present (Table 6). The Minfav medium containing galactose and autoclaved $E$. coli cells $(0.5 \mathrm{mg} / \mathrm{ml})$ alone has supported 
growth in more than 30 consecutive subcultures without the addition of sterols. No growth was detectable in $1 \%$ tryptone (Difco), $1.3 \%$ nutrient broth, $3.7 \%$ brain heart infusion, or $3 \%$ tryptone-soy broth, or in the same media supplemented with a volatile fatty acid mixture, galactose, or autoclaved $E$. coli cells.

Fermentation products. Gas-liquid chromatographic determination of fermentation products was attempted after growth in a medium containing $33 \% \mathrm{CRF}$ and $20 \mu \mathrm{mol}$ of galactose per $\mathrm{ml}$. The results of the assay are depicted in Fig. 9. Comparisons of peak areas indicated that 4 and $20 \mu \mathrm{mol}$ of acetic acid per $\mathrm{ml}$ was produced in duplicate cultures 3 and 4 , respectively. This method was not sufficiently sensitive to measure accurately the small increases when the initial medium contained so much volatile fatty acid added with the rumen fluid. Butyric acid and the compounds giving the slight shoulders on the propionic and butyric acid peaks seem to be used during growth. Lactic acid formation, assayed by the method of Barker and Summerson (1), was 7 and $5 \mu \mathrm{mol} / \mathrm{ml}$, and galactose utilization was 19.3 and $19.9 \mu \mathrm{mol} / \mathrm{ml}$ in cultures 3 and 4 , respectively.

To increase the analytical precision, uniformly labeled ${ }^{14} \mathrm{C}$-galactose was fermented. The products are shown in Table 7 . Formic, acetic, and lactic acids, hydrogen, and $\mathrm{CO}_{2}$ were main products, with traces of propionic acid. The counts in the trichloroacetic acid precipitate represent minimum values, as some cell lysis is to be expected after 10 days of incubation. Calculation of the oxidation-reduction balance of the fermentation products suggests that an unidentified reduced product is formed. The cultures were not tested for ethanol.

The microorganism is classified in the order Mycoplasmatales on the basis of colonial morphology, microscopic morphology, ability to pass a $0.45-\mu \mathrm{m}$ membrane filter at $10 \mathrm{lb} / \mathrm{in}^{2}$, and resistance to penicillin $\mathrm{G}$.

Repeated subculturing in liquid medium without addition of penicillin has not resulted in loss of these properties.

The microorganism is able to grow in a sterol-free medium containing $E$. coli, vitamins, volatile fatty acids, hemin, and galactose, and has therefore been assigned to the family Acholeplasmataceae, genus Acholeplasma (3).

The new isolate differs from the previously described species of Acholeplasma, $A$. axanthum, A. laidlawii, and $A$. granularum, in several physiological characters. All mycoplasmas which grow a naerobically can also grow aerobically (12). This organism has remained obligately anaerobic during 4 years of in vitro cultivation. The formation of an enzyme capable of hydrolyzing peptidoglycan has not been described before among the $\mathrm{Myco}^{-}$ plasmatales. The microorganism ferments ribose, xylose, arabinose, and lactose, not previously reported as fermented by mycoplasmas (4), and also galactose and sucrose, reportedly fermented only by avian strains (14). By use of the slide-agglutination technique for preliminary serological examination, no relationship was detected between the new strain and a limited number of available strains isolated from cattle. On the basis of these properties, the microorganism is classified as a new species, Acholeplasma bactoclasticum (bact-) part of the stem of the Gr. dim. noun bacterium, a small rod; Gr. adj. clasticus breaking; M. L. adj. bactoclasticus bacteriabreaking.

Penicillin-resistant bacteriolytic colonies similar in appearance to $A$. bactoclasticum have been found in all studied samples of rumen contents from both sheep and cows, though the viable count has not exceeded $10^{7} / \mathrm{ml}$. The feed and water of the animals when tested did not
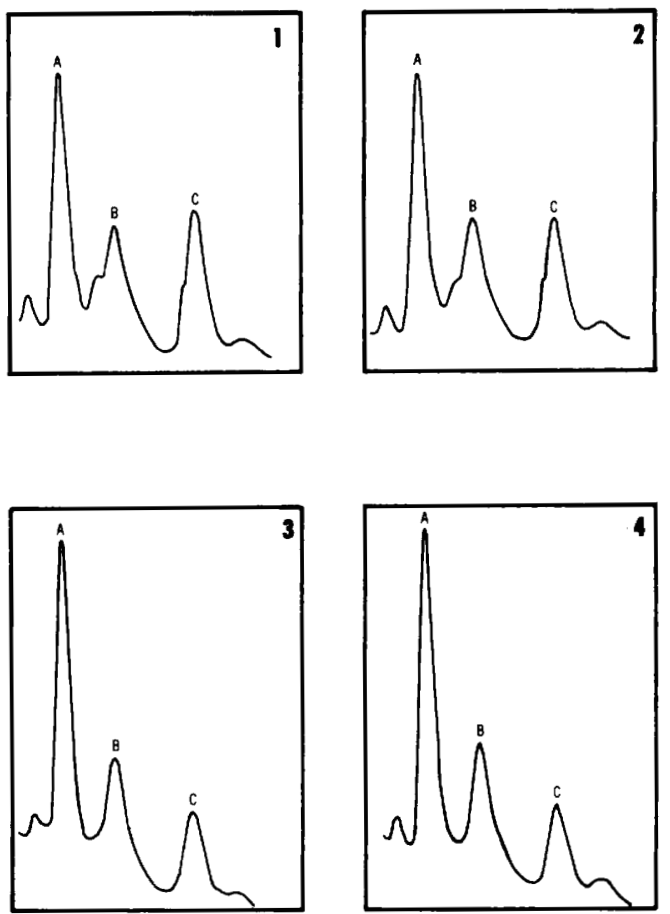

FIG. 9. Gas-liquid chromatographs from samples of acidified, filtered cultures; 1 and 2, before incubation; 3 and 4 , after incubation. $A$, acetic acid; B, propionic acid; $C$, butyric acid. 
TABLE 7. Recovery of labeled $C$ from the fermentation of uniformly labeled ${ }^{14} \mathrm{C}$-galactose by the new microorganism

\begin{tabular}{|c|c|c|c|c|}
\hline \multirow[b]{2}{*}{ Compound } & \multicolumn{2}{|c|}{$\begin{array}{c}\text { Total counts } / \mathrm{ml} \\
\text { of sample (counts } / \mathrm{min})\end{array}$} & \multirow[b]{2}{*}{$\mu \mathrm{Mol}$} & \multirow{2}{*}{$\begin{array}{c}\mu \mathrm{mol} \text { of product } \\
\mu \mathrm{mol} \\
\text { of galactose used }\end{array}$} \\
\hline & Used & Produced & & \\
\hline 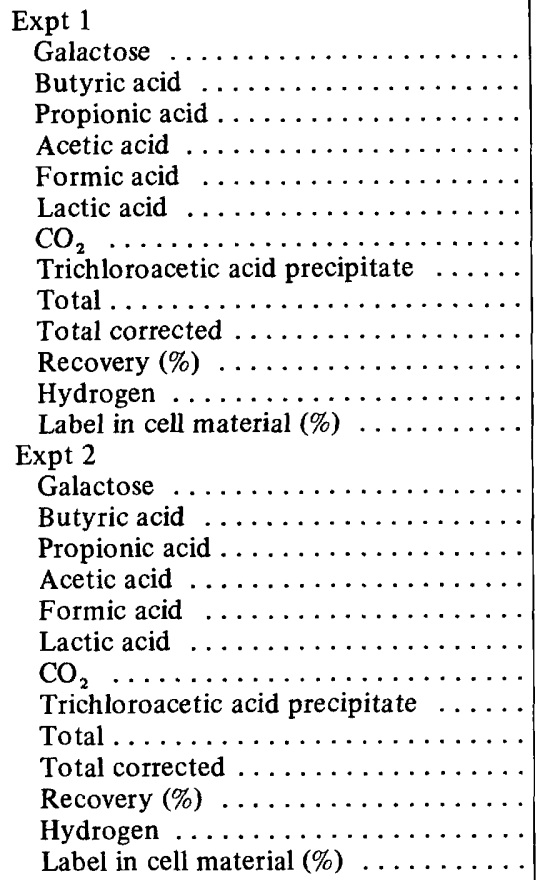 & $2,988,770$ & $\begin{array}{r}3,512 \\
109,197 \\
705,902 \\
523,478 \\
840,090 \\
242,028 \\
207,214 \\
2,627,909 \\
2,837,932 \\
95 \\
9.8 \\
\\
2,555 \\
10,927 \\
257,887 \\
76,433 \\
141,204 \\
41,394 \\
3,802 \\
531,692 \\
566,992 \\
84 \\
4.4\end{array}$ & $\begin{array}{c}44.017 \\
0 \\
3.125 \\
31.179 \\
46.243 \\
23.081 \\
21.381\end{array}$ & $\begin{array}{l}1 \\
0.0057 \\
0.003 \\
1.15 \\
0.683 \\
0.421 \\
0.370\end{array}$ \\
\hline
\end{tabular}

contain significant numbers of these lytic organisms. In view of the volume of the rumen contents, it seems unlikely that the organism could enter the rumen in sufficient numbers from other sources within the animal, such as the nares or the buccal cavity, to maintain a count of about $10^{6} / \mathrm{ml}$. The rumen is thus considered to be the habitat of the organism. The osmotic pressure of rumen fluid, measured as 7.1 and 7.8 atmospheres (6), is within the range of 6.8 to 14.0 atmospheres optimal for many mycoplasmas (8) and close to the estimated internal osmotic pressure of $A$. laidlawii (10).

The microorganism seems unlikely to be the L-form of a rumen bacterium, since it was isolated and subcultivated in the absence of cell wall inhibitors without any "reversion" to walled morphology being detected, and it is apparently capable of maintaining itself in the rumen environment.
Characteristics of Acholeplasma bactoclasticum. A. bactoclasticum is a free-living rumen organism. It is gram negative, usually coccoid, and has a cell envelope with a "unit-membrane" structure. Cells pass through a $0.45-\mu \mathrm{m}$ membrane filter at $10 \mathrm{lb} / \mathrm{in}^{2}$. Surface colonies are small and have a central papilla. Growth depends on strictly anaerobic conditions in the medium.

Glucose, galactose, maltose, lactose, sucrose, arabinose, ribose, and xylose are fermented. Hydrogen, carbon dioxide, formic acid, acetic acid, and lactic acid are formed when galactose is fermented. Arginine is not fermented to yield ammonia. A rich medium with factors present in rumen fluid and $E$. coli cells is required. Cholesterol is not required for growth; neither are serum factors.

Skim milk is cleared by a proteolytic, extracellular enzyme, but ammonia is not formed. A variety of heat-killed cells, including 
those of $E$. coli but not $M$. lysodeikticus, are lysed by an extracellular enzyme which attacks the peptidoglycan layer of the cell wall. Both of these lytic activities are sensitive to oxygen.

Chicken embryos are not killed when inoculated with $A$. bactoclasticum, and no hemolysis of bovine, ovine, or guinea-pig blood in an anaerobic agar medium could be detected.

\section{ACKNOWLEDGMENTS}

The antisera tested were kindly provided by J. Dellinger and D. E. Jasper, University of California, Davis. Electron photomicrographs were prepared by J. Wood. We thank H. E. Adler and A. Da Massa for help and advice, particularly in the seriological series.

This investigation was supported by Public Health Service grant Al-07406 from the National Institute of Allergy and Infectious Diseases.

\section{LITERATURE CITED}

1. Barker, S. B., and W. H. Summerson. 1941. Colorimetric determination of lactic acid in biological material. J. Biol. Chem. 138:539-554.

2. Dienes, L. M. 1939. L variant forms in cultures of various bacteria. J. Infect. Dis. 69:24-42.

3. Edward, D. G., and E. A. Freundt. 1970. Amended nomenclature for strains related to $M$. laidlawii. J. Gen. Microbiol. 62:1-2.

4. Hayflick, L. (ed.). 1969. Fundamental biology of the class Mollicutes order Mycoplasmatales. In
The Mycoplasmatales and the $\mathrm{L}$ phase of bacteria, p. 29. Appleton Century Crofts, New York.

5. Hungate, R. E. 1942. The culture of Eudiplodinium neglectum with experiments on the digestion of cellulose. Biol. Bull. 83:303-319.

6. Hungate, R. E. 1966. The rumen and its microbes. Academic Press Inc., New York.

7. Hungate, R. E. 1969. A roll tube method for cultivation of strict anaerobes, p. 117-132. In J. R. Norris and D. N. Ribbons (ed.), Methods in microbiology, vol. 3B. Academic Press Inc., New York.

8. Leach, R. H. 1962. The osmotic requirements for growth of Mycoplasma. J. Gen. Microbiol. 27:345-354.

9. Martin, H. H., and H. Frank. 1962. Quantitative Baustainanalyse der Stutzmembran in der Zellwand von Escherichia coli B. Naturforschung 17b:190-196.

10. Spears, D. M., and P. J. Provost. 1967. A comparison of the osmotic and passive permeability properties of Mycoplasma laidlawii and Mycoplasma hominis. Can. J. Microbiol. 13:213-225.

11. Ternberg, T. M., F. B. Hershey. 1960. Colorimetric determination of blood ammonia. J. Lab. Clin. Med. 56:767-779.

12. Vandemark, P. J. 1969. Respiratory pathways in the mycoplasmas, p. 499. In L. Hayflick (ed.), The Mycoplasmatales and the $L$ phase of bacteria. Appleton Century Crofts, New York.

13. Wiseman, H. G., and H. M. Irvin. 1957. Determination of organic acids in silage. Agr. Food Chem. 3:213-215.

14. Yamamoto, R., and H. E. Adler. 1958. Characterization of pleuropneumonia-like organisms of avian origin. J. Infect. Dis. 102:243-250. 